\title{
MEMBINGKAI RUANG DIALOG BERAGAMA: BELAJAR DARI HANS KÜNG DAN SEYYED HOSSEIN NASR
}

\author{
Marz Wera \\ Peneliti PENA Institute
}

\begin{abstract}
Religious pluralism in Indonesia is currently in a state of confusion. The reality of religious diversity is insulated by misguided and superficial interpretations. The space for religious dialogue is entangled by group selfishness, squeezed by religious formalism, as well as claims of theological truth. The approach of dialogue, both exclusivism and inclusivism and even pluralism, has not been able to knit religious plurality. Traditions, symbols, rituals, ethical dimensions and the universal core in religions as a precondition of dialogue are actually a ignored. Such pluralism leads to the relativism of the teachings of religions. In that context, the author offers two approach concepts as a new way of interreligious dialogue. " Global Ethics " by Hans Küng and " Perennial Philosophy " by Seyyed Hossein Nasr. These two concepts provide an understanding of the unique and unique dimensions of religions that must be observed and should not be ignored.
\end{abstract}

KEYWORDS: global ethics, Perennial Philosophy, traditions, dialogue, exclusivism, inclusivism, pluralism.

ABSTRAK: Pluralisme agama di Indonesia pada saat ini berada di dalam kondisi membingungkan. Realitas keanekaragaman agama diisolasi oleh penafsiran yang menyesatkan dan dangkal. Ruang untuk dialog agamawi dijerat oleh keegoisan kelompok, digencet oleh formalisme agama, dan juga klaim-klaim kebenaran teologis. Pendekatan dialog yang mencakup eksklusivisme, inklusivisme, dan bahkan pluralisme, tidak mampu merajut pluralitas agama. Tradisi-tradisi, simbol-simbol, ritual-ritual, dimensi-dimensi etis, dan inti universal di 
dalam agama-agama sebagai sebuah prakondisi dialog itu ternyata diabaikan. Pluralisme yang demikian akan membawa kepada relativisme di dalam ajaran-ajaran dari agama-agama. Di dalam konteks itu, penulis menawarkan dua konsep pendekatan sebagai sebuah gagasan baru untuk dialog antar agama. " Etika Global " oleh Hans Küng dan " Filsafat Perennial " oleh Seyyed Hossein Nasr. Dua konsep ini memberikan sebuah pemahaman mengenai apa itu keunikan dan dimensi-dimensi keunikan dari agama yang harus diamati dan seharusnya tidak diabaikan.

KATA-KATA KUNCI: etika global, filsafat perennial, tradisi, dialog, ekslusivisme, inklusivisme, pluralisme.

\section{Pendahuluan}

Hari-hari ini, "kita" dan "mereka" mewarnai hidup beragama. Ini bisa kita saksikan sepanjang tahun 2016, bahkan hingga tahun 2017 ini. Komnas HAM mencatat sepanjang tahun 2016 terdapat 97 kasus intoleransi agama. Fenomena ini justru berbalik dengan penilaian orang bahwa Indonesia selalu menjunjung tinggi nilai-nilai toleransi. Fenomena ini juga menandai tingkat intoleransi agama yang terus meningkat empat tahun terakhir. Komnas HAM mencatat pada tahun 2014 terdapat 74 kasus, tahun 2015 terdapat 87 kasus, dan 2016 terdapat 97 kasus. Kasuskasus ini disinyalir akan terus meningkat di tahun 2017. Apalagi tahun 2018 sudah masuk dalam tahun politik. Ketika agama masuk dalam proses politik, maka gerakan massa intoleran akan mudah diaduk-aduk emosinya untuk melakukan aksi intoleransi.

Dari deretan kasus-kasus intoleransi agama di atas, penulis memperhatikan ada dua kasus yang paling mendapat perhatian dan menguras energi berbagai pihak untuk duduk bersama membuka ruang dialog. Bahkan orang beramai-ramai saling menghujat di media sosial. Pertama, kasus pembubaran paksa kegiatan ibadah bertajuk Kebaktian Kebangunan Rohani (KKR) yang berlangsung di Sabuga ITB Bandung pada penghujung tahun 2016, menjelang perayaan Natal. Kedua, adalah 
kasus tuduhan penistaan agama terhadap Basuki Tjahaja Purnama atau Ahok (gubernur DKI Jakarta saat itu) yang bertepatan dengan musim Pilkada DKI tahun 2017. Dua kasus ini patut menjadi refleksi bagi bangsa Indonesia yang menganut Pancasila sebagai pedoman hidup berbangsa dan bernegara.

Akankah hidup beragama mampu memberikan jawaban kontekstual atas situasi ini? Kalau tindakan apologetis ${ }^{1}$ bahwa semua agama selalu hadir untuk mendamaikan, lantas kenapa masih ada "kita" dan "mereka" dalam hidup beragama? Di ruang publik orang gampang mengobarkan sentimen agama. Apalagi ada proses politik berlangsung. Perusahaan pun membawa label agama untuk menipu konsumen. Kaum agamawan rajin berkoar menjual kesucian untuk mengisi kantongnya. Dengan posisi agama masuk dalam pemenuhan hasrat untuk mengejar kekuasaan dalam ruang apapun (kelompok agama mana saja) adalah tindakan tak menghormati dan bahkan merendahkan martabat agama itu sendiri. Karena ajaran dan nilai-nilai moral yang luhur telah diturunkan harkatnya dan dijadikan alat untuk mendapat kekuasaan yang fana. Dengan kata lain, suatu bonum maximum direndahkan martabatnya menjadi alat bagi suatu minus malum. ${ }^{2}$

Kalau Pancasila lahir sebagai simpul perekat "kita" dan "mereka", lantas apa yang menyebabkan fenomena ini terjadi? Apakah simpul perekat yang namanya Pancasila ini perlu dirumuskan ulang atau cara kita memaknai dan mewujudkan Pancasila yang salah? Mungkin lebih dalam lagi, apakah agama sedemikian berbahayanya hingga membenarkan tindakan destruktif terhadap sesama yang berbeda agama? Lalu di manakah pedoman etis beragama yang harus dilekatkan pada masing-masing penganut agama agar mampu mewarnai suasana yang lebih damai dan harmonis? Umat beragama kini mudah terjebak dalam mobilisasi massa untuk menekan hingga mengkafirkan yang

\footnotetext{
1 Tindakan membela diri sesuai dengan keyakinan.

2 Ignas Kleden, "Agama dan Negara", Kompas, 30 Mei 2017.
} 
berbeda. Berpaling ke Haryatmoko, "hidup beragama jangan hanya mendapat stempel sebagai perusahaan yang melulu memproduksi larangan". ${ }^{3}$ Paham agama sebagai sistem berpikir radikal dalam doktrin iman seseorang ke arah klaim kebenaran teologis. Gerakan iman dipahami sebanding dengan gerakan destruktif. Berbahayanya, "agama direduksi hanya sebagai ideologi".4

Dalam negara hukum modern, yang religius dipisahkan dari yang moral, maka kesalehan religius adalah perkara privat yang tak perlu dibawa ke ruang publik. Mendesakkan konsep partikular tentang perintah Tuhan kepada institusi-institusi publik dihitung sebagai politik sektarian yang dapat mengancam kemajemukan. Namun, sikap mendua akan mengubah kesalehan menjadi kemunafikan. Masalah kesalehan adalah bagaimana yang religius, yaitu yang baik menurut Tuhan, dan yang moral, yaitu yang baik menurut manusia, dapat disatukan sekaligus dalam satu ide. ${ }^{5}$

Pengaruh lainnya adalah ketika kelahiran teknologi yang membuat manusia semakin otonom, lalu lintas informasi tidak dicermati dengan baik, penafsiran beralih dari ortodoksi ke heterodoksi. Orang mudah terjebak oleh tafsiran sesat dan dangkal. Kesempitan wawasan yang mudah terkecoh dengan manipulasi. Etika komunikasi tak berdaya menghadapi maraknya ujaran kebencian di media. "Kekerasan fisik, pornografi, kekerasan virtual, dan kekerasan simbolik merajalela tanpa ada struktur kuat yang melawannya. Kekuatan moral seperti dibuat tak berdaya. Agama cenderung tergoda untuk mengusulkan pemecahan represif". 6

Dalam tulisan ini, penulis akan mengajak kita untuk bersama merefleksikan fenomena di atas pada gagasan dua tokoh inspiratif yang

\footnotetext{
3 Budhy Munawar Rachman (ed.), Membela Kebebasan Beragama, "Percakapan dengan Haryatmoko" buku 2 (Jakarta: LSAF, 2015), 660.

4 Haryatmoko, "Agama: Etika Atasi Kekerasan?", Kompas, 17 April 2000.

5 F. Budi Hadirman, "Kesalehan dan Kekerasan", Kompas, 6 Januari 2017.

6 Haryatmoko, "Kekerasan dalam Media", Kompas, 3 Juli 2008.
} 
sudah teruji dalam konteks dialog beragama. Konsep kedua tokoh ini, menurut penulis patut dipelajari sebagai gambaran untuk memahami lebih dalam soal keunikan dan kekhasan masing-masing agama yang harus diperhatikan, sekaligus tidak boleh diabaikan. Kita akan tetap yakin pada kekhasan dan keunikan kita tanpa harus mengabaikan orang lain, sebaliknya ada apresiasi dan saling mengakui sebagai keindahan hakiki yang hadir untuk saling menghiasi belantara keberagaman Nusantara.

Dengan berkaca pada gagasan kedua tokoh tersebut, penulis lalu temukan dan refleksikan, yang juga wujud refleksi pengalaman selama bertemu dan berinteraksi dengan sesama umat yang berbeda agama. Aktivitas dialog yang diusung keduanya diyakini sangat cocok sebagai cermin dalam dialog agama. Kedua tokoh ini mengajak kita untuk kembali melihat ke dalam diri masing-masing agama dengan segala kekhasan dan keunikan sebelum masuk ke ruang dialog yang lebih plural. Ada semacam refleksi internal atas iman, pengetahuan akan agamanya sendiri, serta pengakuan pada realitas nilai yang universal dari agama yang berbeda sebagai mitra dialog. Penafsiran gagasan dan rumusan keduanya melalui perjalanan pengalaman penulis selama menjadi aktivis dialog antaragama. Gagasan Küng dan Nasr, menurut penulis menyentuh sampai pada tata nilai otentik bangsa Indonesia yaitu Pancasila.

\section{Pluralisme Agama dan Tantangannya}

Dalam bukunya Theology of the Third Millennium (1988), Hans Küng menggambarkan bahwa periode ini sebagai transisi dari era modern ke era postmodern. Dari sinilah agama mengalami semacam krisis kredibilitas. Melalui buku tersebut Küng mencari jalan keluar bagi agama dalam melakukan fungsi kritis bagi kehidupan manusia baik secara individu maupun bersama. ${ }^{7}$

7 Hans Küng, Theology for the Third Millennium - An Ecumenical View (New York: 
Pluralitas dalam pluralisme agama adalah realitas yang sudah jelas-jelas terbukti. Proses pluralisasi berjalan beriringan dengan kemodernan. Dalam konteks itu, pola pikir umat beragama mulai mengalami pengaruh postmodern. Kemajuan teknologi mengalienasi manusia dari nilai-nilai kemanusiaan universal dan sikap netral dalam memperlakukan sesama warga negara. Urusan internal agama direduksi untuk diperdebatkan dengan isu miring di ruang publik. Kenyataan yang kompleks ini membuka refleksi bagi para pemikir keagamaan untuk menilai kembali doktrin-doktrin teologisnya. Hidup beragama terlibat dalam dialog yang intens, namun upaya ini tidak bisa menghapuskan kesalahpahaman antara sesama pemeluk agama dalam memandang secara serius identitas agama seseorang. ${ }^{8}$

Gerardette Phillips memaparkan tiga bahaya dalam pluralisme. Pertama, cacat secara metodologis, ini dilandasi sebuah upaya bersama untuk mencari apa yang umum bagi semua agama, maka para pluralis justru mengabaikan secara serius unsur-unsur penting serta keunikan agama-agama. Contohnya konsep Trinitas dalam Katolik, Nubuat Nabi Muhammad dalam Islam, Empat Kesunyatan Mulia dalam Buddha, Kristen dengan tradisinya, tradisi Nyepi dalam umat Hindu, serta jalan spiritual dalam umat Konghucu dengan tradisi Imleknya. Kedua, bermasalah secara moral, ini mengarah pada tendensi pluralisme intelektual keagamaan secara umum. Tentunya bermasalah, karena semua tradisi agama merupakan cara manusia merespons kepada Tuhan dengan berbagai kekhasan dan perbedaan yang cukup spesifik. Ketiga, pluralisme secara logis mustahil, orang akan dengan gampangnya merelatifkan bahwa semua gagasan agama adalah sama sesuai dengan pemahamannya sendiri. Ini akan cenderung memaksakan orang lain yang berbeda untuk mempercayai begitu saja. ${ }^{9}$

Doubleday, 1988), xv.

8 Gerardette Phillips, Melampaui Pluralisme (Malang: Madani, 2016), iii.

$9 \quad$ Ibid., 231-44. 
Pluralisme adalah wujud sejati kebhinekaan dalam ikatan keadaban. ${ }^{10}$ Maka penting bagi umat beragama untuk menyadari bahwa perkembangan teologi di masa yang akan datang, dan agama mana pun meyakini bahwa merupakan hasil langsung dari dialog yang serius dengan agama-agama lain. ${ }^{11}$ Era keterbukaan mendorong pemeluk agama untuk menjadikan dialog sebagai sikap dasar kerjasama antaragama. Ini mengikuti perubahan kebudayaan modern yang bersifat pluralistik dan kebebasan akal sehat.

Dalam berdialog adalah orang saling berbagi pengalaman iman antaragama. Membuka kesempatan untuk saling mendengarkan kebijaksanaan dan persoalan-persoalan dari agama lain.12 Dengan dialog sesama pemeluk agama saling mengakui kehadiran kehendak Allah yang menyelamatkan dalam ajaran dan praktek dari agama-agama yang bersangkutan. ${ }^{13}$ Para pemikir filsafat dan teologi merumuskan bahwa pemahaman pluralisme agama terjadi jika pemeluk dari setiap agama menyingkirkan pandangannya sendiri dan berusaha menerima pihak lain dan "melihat"' alam semesta agamanya melalui konsep-konsep pihak lain. ${ }^{14}$ Ini sebagai upaya untuk melahirkan reaksi positif pengakuan timbal balik antar agama dengan terbuka untuk saling menerima.

Namun yang terjadi akhir-akhir ini dialog beragama justru terkurung oleh persaingan mencari eksistensi diri ke dalam percaturan kekuasaan. Ada narasi-narasi kecil dengan alibi atas nama kebebasan

\footnotetext{
10 Nurcholish Madjid, "Genuine Engagement of Diversities Within the Bonds of Civility" dalam Republika, 10 Agustus 1999. Lihat juga, N Madjid, "Fat Soen", Jakarta: Republika, 2002: 172.

11 Budhy Munawar Rachman, Prolog dalam Gerardette Phillips, Melampaui Pluralisme, viii.

12 Ibid., viii-ix.

13 Harold Coward, Pluralisme: Tantangan bagi Agama-agama (Yogyakarta: Kanisius, 1989), 34. Juga O'Keeffe dalam David Archard (ed), "Philosophy and Pluralism," (Cambridge: Cambridge University Press) 1996: 61-62.

14 Budhy Munawar Rachman, Islam dan Liberalisme (Jakarta: Friedrich Nauman Stiftung, 2011), 38. Juga Al-Jauhari dalam Achmad Jahuri, “Ideologi Kaum Reformis: Melacak Pandangan Keagamaan Muhammadyah Periode Awal," (Jakarta: LPAM), 2001:82, Budhy Munawar Rachman, Prolog dalam Gerardette Phillips, Melampaui Pluralisme, viii.
} 
mengemukakan pendapat di muka umum. Pola ini akan membawa kita pada pola dialog beragama di masa kolonial. Di mana dialog yang dikondisikan oleh pemerintah kolonial diwarnai gerakan-gerakan misioner untuk bisa merebut pengikut yang banyak. Yang paling berperan adalah lembaga-lembaga, yang secara khusus memegang prinsip doktrin iman agama masing-masing. ${ }^{15}$

Ini berbahaya karena pluralisme agama marak dengan gerakan samar, yang diam-diam menjadi simpul ideologi politik dan ideologi agama. Pola dialog yang bermaksud untuk menghindari konflik, sehingga yang terlibat dalam dialog hanyalah tokoh-tokoh agama, pemerintahan, lembaga-lembaga masyarakat, hanya tataran kaum elit. Mengkondisikan demi stabilitas sementara waktu tapi di kesempatan lain diam-diam melakukan gerakan samar demi menguasai dan mendominasi yang lain. "Prinsip demokrasi mengatur bahwa agama secara prosedural harus ada di ruang privat. Namun, secara substansial agama mesti mengejawantahkan diri dalam ruang publik melalui perjuangan kebaikan dan kebajikan yang universal."16

Pada konteks yang lain masih ada hambatan dalam aspek teologis. Misalnya dalam Kristen, evangelisasi merupakan suatu dialog, namun menjadi persoalan ketika evangelisasi identik dengan pengajaran pada semangat pertobatan orang lain. Ini menjadi domain yang harus benarbenar diperhatikan oleh para tokoh agama dalam memberikan pemahaman baru dengan tafsiran baru ke umat agar bisa menerima dengan baik dan sederhana sehingga umat dengan sendirinya punya inisiatif dalam menjalankan dialog.

Juga maraknya isu-isu yang dimainkan oleh tokoh-tokoh berpengaruh, seperti isu kristenisasi. Ini memunculkan perdebatan yang menakut-nakuti pemeluk agama lain. Keragaman narasi internal dalam

15 Th. Sumartana, St. Sunardi \& Farid Wajidi, “Menuju Dialog Antar Iman”, Pengantar dalam Dialog: Kritik \& Identitas Agama (Yogyakarta: DIAN/Interfidei, 1993), ix-x.

16 Boni Hargens, “Indonesia dan Titik Nol”, Kompas, 5 April 2017. 
agama mengemuka sebagai dalil untuk mematikan ruang gerak agama lain. Sementara dari arah sebaliknya, ketika ada kaum inklusif agama yang sama membela agama lain dalam dalil universalitas nilai, justru dituduh sebagai antek Kristen, Zionisme, ateis, dan lain-lain.

Pluralisme agama adalah pengalaman akan kesadaran dari dalam diri seseorang sesuai dengan iman agamanya menuju ke universalitas agama-agama. Pengalaman ini hadir meleburkan diri ke dalam situasi sejarah peradaban, dengan segala sosio-kultural yang beragam. Dari konteks inilah vitalitas agama ditantang untuk mampu mengantarkan para pemeluknya ke pengalaman liberatif sebagai nilai inti agama dalam memanifestasikan ke peristiwa hidup sehari-hari.

Bahwa agama tanpa spiritualitas yang mendalam serta moralitas yang luhur, justru bisa jadi sumber bencana, sumber datangnya kiamat kemanusiaan. Tanpa cinta, agama bisa jadi sumber sikap radikal dan agresif. Sebagaimana kita lihat dalam beberapa tahun belakangan ini, agama telah disalahpahami dan disalahpraktikkan sehingga jadi pemicu kekerasan dan peperangan. ${ }^{17}$

\section{Keterbukaan pada Pluralitas Agama}

Dalam konteks itu, pluralisme agama adalah pemahaman akan ajaran, keyakinan pada konsep keselamatan secara umum dari sisi agamanya dan keyakinan pada kebenaran teologis adalah kekhasan internal masing-masing agama yang perlu dihargai. Pada tingkat penghayatan lebih dalam, semua insan perlu memahami bahwa semua agama bukan hanya peninggalan masa lalu dan bukan hanya sekadar perjalanan peradaban dengan segala aspek teoritisnya, tetapi bagian dari konstruksi realitas yang memberikan pendasaran nilai-nilai hakiki yang sudah menjelma dalam sejarah peristiwa hidup manusia.

Pluralitas terbuka bagi penganut agama lain untuk menemukan Tuhan lewat jalan berbeda. Beranjak dari keunikan internal ke

17 Haidar Bagir, “Cinta Sebagai Asas Agama”, Kompas, 18 Juli 2016. 
universalitas Sang Pencipta. Melalui pluralitas agama, manusia menimba pengalaman kebaruan atas kebenaran. Kebenaran Ilahi akan semakin kuat dan membawa manusia pada penghayatan terdalam. Setiap pengalaman dialog memperluas wilayah pengalaman partikular dalam kebenaran agama-agama. Dan inilah cermin dari sikap inklusivitas, sedangkan sikap eksklusivitas selalu merasa paling benar yang justru berujung pada puncak kemunafikan.

Raimundo Panikkar merumuskan bahwa dalam melakukan dialog dan mengembangkan kesadaran inklusif, sedikitnya akan menyentuh dua hal. Pertama, menghidupkan suatu kesadaran tentang pokok iman orang lain. Kedua, mengarahkan kepada kerjasama untuk memecahkan persoalan kemanusiaan bersama di masyarakat. ${ }^{18}$ Pluralitas agama sudah menjelma dan ada sejak zaman para nabi yang merupakan tugas kemanusiaan yang universal.

Orang jangan hanya fokus pada dimensi formal agama-agama, melainkan bagaimana agama hadir dalam menangani realitas sosial. Hidup sehari-hari merupakan keaslian bagi manusia untuk menampilkan wajah agama yang otentik. Wujudnya menghadirkan pluralitas nilai untuk sebaik mungkin menjalin komunikasi yang intens tentang ajaran-ajaran iman agama masing-masing ke wilayah dialog agama. Melalui konsep pluralitas ini kita saling belajar untuk memahami, sehingga setiap waktu selalu ada kesempatan untuk berdialog mewujudkan nilai-nilai kehidupan bersama. "implikasi kesadaran ini ini menyangkut kesediaan untuk menyesuaikan diri di bawah cahaya kesadaran ketuhanan."19

Kesadaran ini bersumber pada sifat ilahiah. Dan tergantung manusia dalam meyakini dan memutlakkan kebenaran akan

\footnotetext{
18 Raimundo Panikkar, "The Unknown Christ Of Hinduism: Towards An Ecumenical Christophany" dalam Madrid: Derechos de publicación (1981): 56-60.

19 Budhy Munawar Rachman, "Kesatuan Trasendental dalam Agama: Perspektif Islam tentang Kesamaan Agama-agama" dalam Dialog: Kritik \& Identitas Agama (Yogyakarta: DIAN/Interfidei, 1993), 123.
} 
keyakinannya pada keilahian. Manusia punya keterbatasan dalam menjangkau dan menangkap kemutlakan sebagai doktrin kebenaran. Sehingga perlu memperhatikan keyakinan yang lain, memilih jalan yang berbeda tetapi menuju tujuan yang sama. Dan agama tidak pernah salah memberikan nilai serta akad moral bagi manusia. Yang salah adalah cara manusia memahami dan memanifestasikannya.

Konflik beragama muncul karena orang sering membandingkan cara dirinya beragama dengan orang lain, yang sebenarnya bukan pilihannya secara bebas dan akal sehat. Karena hakekat orang beragama adalah mengikuti warisan lingkungan hidupnya mulai dari keluarga hingga masyarakat. Bila ada kesadaran, pemahaman beragama akan tersadarkan sepenuhnya, akan keterbatasan dan ketidakmutlakan manusia dalam mengontrol iman beragama. ${ }^{20}$ Beragama didasarkan pada kesadaran bahwa semua agama selalu mengusung ajaran kebenaran yang tak pernah secara utuh dan sempurna ditangkap oleh manusia, yang secara hakikat sebagai keutuhan ciptaan-Nya, manusia terbatas dalam memahami segala sesuatu.

Melalui kerjasama, agama sebagai jalan keselamatan akan melahirkan berbagai kemungkinan dalam proses tumbuh kembang manusia. Dialog menjadi nilai esensial dalam merangsang keberagaman yang dinamis untuk terus dipupuk dalam peristiwa hidup bersama. Melalui kerjasama, kita belajar kepada orang lain tentang diri kita, begitu juga sebaliknya. Orang akan saling belajar hingga mencapai puncak kedewasaan dan keterbukaan menuju kematangan iman beragama secara otentik.

\section{Konsep "Etika Global" Hans Küng}

Konsep Etika Global dimulai dengan deklarasi, "Declaration Toward a Global Ethic." Sekaligus mengawali dua karya yaitu

\footnotetext{
20 Djohan Effendi, “Dialog Antar Agama: Bisakah Melahirkan Teologi Kerukunan” dalam Prisma 5 (Juni 1978): 16-7.
} 
Justifikasi $^{21}$ dan Etika Global.22 Kemudian pada tahun 1990 Küng merumuskan hasil penelitiannya tentang standar etis fundamental agama dengan sebuah buku programatik berjudul Global Responsibility: In Search of a New World Ethic. Buku ini sebagai langkah awal menuju deklarasi Etika Gobal melalui persetujuan Parlemen Dewan Agamaagama Dunia di Chicago pada tahun 1993.23

Kedudukan Hans Küng sebagai seorang pengajar sempat menimbulkan kontroversi, banyak peringatan dan surat-surat resmi dari uskup-uskup Jerman dikirim ke Tübingen tempatnya ia mengajar teologi Katolik. Hingga pada 18 Desember 1979 pihak Roma mencabut missio canonica (hak resmi Vatikan) untuk mengajar doktrin resmi Gereja Katolik. Alasannya bahwa ajaran Küng dinilai tidak sesuai lagi dengan semangat ajaran Katolik. ${ }^{24}$ Karena gagasan Küng yang meragukan dogma tentang infalibilitas ${ }^{25}$ di dalam gereja, tidak mengakui adanya kemungkinan salah dari pernyataan-pernyataan doktrinal yang dikeluarkan Gereja. ${ }^{26}$

Meskipun demikian teolog kelahiran Swiss ini masih mengakui dirinya sebagai seorang teolog dan anggota Gereja Katolik. Hubungan dilematis ini tergambar dalam semboyan, "Gereja Katolik, yes! Inquisisi27

\footnotetext{
21 Nilai minimum yang dibutuhkan umum, standar dan sikap dasar dalam kehidupan umat beragama.

22 Deklarasi ini memiliki nama Declaration Toward a Global Ethic bukan Etika Global. Etika berarti suatu sikap moral dasar manusiawi, sedangkan etika menunjuk pada dimensi filosofis dan teologi dari sikap, nilai-nilai dan norma-norma moral.

23 Gerardette Phillips, Melampui Pluralisme (Malang: Madani, 2016), 85.

24 St Sunardi, Dialog: Cara Baru Beragama (Sumbangan Hans Küng bagi dialog antaragama), (Yogyakarta: DIAN/Interfidei, 1993), 59.

25 Infalibilitas kepausan adalah dogma yang menyatakan bahwa, dengan kuasa Roh Kudus, Sri Paus dilindungi dari (bahkan) kemungkinan membuat kesalahan ketika ia secara resmi menyatakan atau mengumumkan kepada Gereja mengenai sebuah ajaran dasar tentang iman atau moralitas seperti yang terkandung di wahyu Tuhan.

26 Ibidem, gugatan Küng tentang dogma infalibilitas dituangkan dalam bukunya Infallible: An Inquiry (Collins, London, 1971), 11.

27 Istilah yang secara luas digunakan untuk menyebut pengadilan terhadap bidaah yang didakwa bertentangan dengan Gereja Katolik Roma.
} 
Roma, no!"28 Sikap dan pendiriannya yang tegas sudah tampak sejak meniti karirnya sebagai seorang teolog dengan spesialisasi teologi dogmatik ${ }^{29}$ dan ekumenis ${ }^{30}$. Tahun 1962 masih terhitung sebagai seorang teolog muda, Küng mendapat kepercayaan dari mendiang Paus Yohannes XXIII untuk tergabung dalam kelompok ahli Konsili Vatikan II. Secara spesifik mengemban tugas memberikan kuliah kepada para uskup tentang reform dalam bidang liturgi dan doktrin, persoalan ekumenis, serta hubungan antara kepausan dan para uskup. ${ }^{31}$

Pada paruh tahun 1988 Küng menulis buku dengan judul Theology for Third Millenium. Ia melukiskan periode masa itu sebagai masa transisi dari era modern ke postmodern, ${ }^{32}$ di mana agama mengalami krisis kredibilitas. Sehingga perlu rumusan baru bagi agama untuk menjalankan fungsi kritis bagi kehidupan manusia baik secara individual maupun bersama, agar bisa menemukan kembali kredibilitas dan vitalitasnya. ${ }^{33}$

Ciri-ciri era ini adalah komitmen yang terarah pada nilai kemanusiaan dan lingkungan hidup. Nilai-nilai diangkat lagi di atas nilai-nilai artifisial yang berdasarkan pada dewa-dewa palsu dari

\footnotetext{
28 Hans Küng, "Why I Remain a Catholic" dalam Leonard Swidler (ed.), Consensus in Theology? A dialogue with Hans Küng and Edward Schillebeekx (Westminster: Philadelphia, 1980), 165.

29 Refleksi kritis sistematis atas iman Katolik sekaligus merenungkan kebenaran pokokpokok iman Katolik dalam terang wahyu ilahi, yaitu Tradisi dan Kitab Suci.

30 Berasal dari bahasa Yunani oikos (=rumah) dan menein (=tinggal), sehingga oikoumene berarti "rumah yang ditinggali" atau "dunia yang didiami". Dalam pengertiannya yang paling luas, ekumenisme berarti inisiatif keagamaan menuju keesaan di seluruh dunia.

31 Hermann Haering \& Karl-Josef Kuschel (eds.) dengan Margaret Gentner, Hans Küng: His Work and His Way (Fount: London, 1979), 18.1.

32 Gerakan abad akhir ke-20 dalam seni, arsitektur, dan kritik, yang melanjutkan modernisme. Termasuk dalam pascamodernisme adalah interpretasi skeptis terhadap budaya, sastra, seni, filsafat, sejarah, ekonomi, arsitektur, fiksi, dan kritik sastra. Pascamodernisme sering dikaitkan dengan dekonstruksi dan pascastrukturalisme karena penggunaannya sebagai istilah mendapatkan popularitas yang signifikan pada waktu yang sama dengan pascastrukturalisme, yaitu dalam abad kedua puluh.

33 St Sunardi, Dialog: Cara Baru Beragama (Sumbangan Hans Küng bagi dialog antaragama), (Yogyakarta: DIAN/Interfidei, 1993), 62.
} 
modernisme. Di tengah keprihatinan manusia untuk melindungi kemanusiaan inilah peran agama sungguh dinantikan. ${ }^{34}$ Dari sinilah hubungan antara agama dan manusia maupun antaragama mengalami pembaharuan secara dewasa, Küng melihat bukan hanya tantangan baru melainkan kesempatan baru untuk meninjau kembali. ${ }^{35}$

Gagasan ini diawali oleh kebuntuan atas konsep dan gagasan para filsuf ateistik modern seperti Feuerbach, Marx dan Nietzsche yang secara sistematis dan ilmiah ingin meniadakan agama sekaligus mengabaikan kodrat manusia. ${ }^{36}$ Para filsuf ini lupa bahwa kebebasan manusia akan berujung pada proses perbudakan bahkan sampai pada gejala dehumanisasi ${ }^{37}$ tanpa batas.

Posisi teologis Küng adalah agama tidak bertentangan dengan kemanusiaan tapi menyempurnakan kemanusiaan. ${ }^{38}$ Gagasan ini mendorong Küng berkomitmen dengan menulis buku-buku secara masif guna menjawab isu postmodern, di antaranya: Does God Exist? (1980: ed. Jerman 1978), Eternal Life? (1984: ed. 1978), dan yang fenomenal adalah ringkasan iman Kristen dengan istilah summa dalam judul On Being a Christian (1977: ed. 1978).

Posisi teologis Küng sebagian besar terangkum dalam buku Justification: Doktrine of Karl Barth and Catholic Reflection. Ia melihat implikasi sosial dari agama. Agama harus mengedepankan pengalaman dan interaksi hidup bersama sesuai konteks budaya dan tradisi masyarakat di mana mereka hidup dan bertumbuh. Agama dalam diri manusia adalah Tuhan bagi seluruh umat manusia. Sebagai penyingkapan dalam mengungkapkan dimensi universal agama-agama

\footnotetext{
$34 \quad$ Ibid., 63.

35 Thomas Quinn \& Stefanie Heiss, interview Hans Küng dalam Lufthansa Bordbuch, 5/91, 29-34. Dalam St Sunardi, Dialog: Cara Baru Beragama (Sumbangan Hans Küng bagi dialog antar agama), (Yogyakarta: DIAN/Interfidei, 1993), 63.

36 Hans Küng, Theology for the Third Millenium (1988), 6.

37 Suatu proses yang menjadikan manusia tidak sesuai dengan kodratnya sebagai manusia.

38 St Sunardi, Dialog: Cara Baru Beragama (Sumbangan Hans Küng bagi dialog antar agama), (Yogyakarta: DIAN/Interfidei, 1993), 64
} 
dengan kesamaan yang dimiliki ketimbang mencari-cari apa yang memisahkan.

Teologi agama-agama harus menjadi teologi yang hidup dan mampu berdialog secara bertanggung jawab. Agama-agama harus berteologi dengan niat menuju perubahan universal melampui batasbatas pengakuan identitas manusia. Secara lebih rinci Küng menyatakan bahwa sebuah teologi yang bertanggung jawab untuk rekonsiliasi, memperluas konsep ekumenisme agama-agama, dan tentu saja seluruh bumi yang dihuni dan dengan demikian bekerja untuk perdamaian baik secara teoritis maupun praktis. ${ }^{39}$

Perlu ada satu titik kesamaan sebagai ikatan bersama menuju perdamaian. Karena "tidak ada keberlangsungan hidup tanpa sebuah etika dunia. Tidak ada perdamaian dunia tanpa perdamaian di antara agama-agama. Tidak ada perdamaian antara agama-agama tanpa dialog di antara agama-agama."40 Ia meyakini perlunya kerjasama secara tanggung jawab dan terbuka untuk saling merangkul melampui identitas agama-agama.

Etika globalnya memuat empat prinsip dasar. Pertama, tidak ada tatanan global baru tanpa suatu etika global. Tanggung jawab manusia atas tatanan global yang lebih baik pada keterlibatan dan semangat dasar keyakinan etis menuju universalitas kemanusiaan. Kedua, sebuah tuntutan fundamental: setiap manusia harus diperlakukan secara manusiawi. Apa yang Anda sendiri tidak inginkan, jangan lakukan pada orang lain, atau apa pun yang Anda ingin orang lakukan untuk Anda, lakukan juga untuk mereka. Ketiga, empat pedoman, yaitu: nonkekerasan dan menghormati kehidupan, solidaritas dan tatanan ekonomi yang adil, toleransi dan hidup sejati, hak-hak yang sama dan kemitraan di antara laki-laki dan perempuan. Keempat, suatu transformasi

\footnotetext{
39 Hans Küng, My Struggle for Freedom Memoirs-1, J. Bowden. (terj.), (USA: Wm. B. Eerdmans Company, 2003), 148.

40 Hans Küng, Global Responsibility in Search of a New World Ethic (New York: The Crossroad Publishing Company, 1991), xv.
} 
kesadaran. Bahwa ada kesadaran baru menuju rasionalitas masyarakat yang plural dalam beragama. ${ }^{41}$

Menurutnya, suatu agama dikatakan benar dan baik bila dan sejauh agama itu manusiawi, tidak menghilangkan dan menghancurkan kemanusiaan, tetapi melindungi dan memajukannya. ${ }^{42}$ Dalam realitas hidup, manusia akan selalu menemukan setiap perbedaan atas cara berperilaku dan bersikap, penghargaan terhadap sesama, dan rasa saling menghormati. Seseorang dikatakan Katolik, berarti orang tersebut menjadi manusia secara Katolik, maksudnya agama dalam konteks ini adalah konkret, hakekat untuk memahami proses menjadinya manusia. Sehingga kita bisa tangkap bahwa kemanusiaan itu secara alamiah bermula dari dimensi religius, sekaligus agama bermula dari dimensi manusiawi. ${ }^{43}$

Usaha Küng adalah bagaimana memahami agama bukan secara teoritis, tetapi hidup dan penjelmaannya yang kita hayati dalam peristiwa hidup sehari-hari. Realitas hidup itu soal sikap yang mempercayai hidup, pendekatan dan ruang hidup bersama, cara memaknai hidup, bagaimana menjalin relasi sekaligus perjumpaan dengan sesama. Adanya kesadaran dalam proses bertumbuh dan komitmen hidup baik bersama, memberi makna bagi sesama, patuh pada nilai dan norma hidup bersama dalam masyarakat.

\section{Konsep "Filsafat Perennial"' Seyyed Hossein Nasr}

Warisan intelektual dan spiritualnya dipengaruhi oleh tiga tokoh penting. Ketiga penafsir itu adalah Rene Guẻnon, Ananda K Coomaraswamy dan Frithjof Schoun. Kelompok ini membedakan diri

\footnotetext{
41 Hans Küng \& Karl-Josef Kuschel, A Global Ethic the Declaration of the Parliament of World Religions (USA: Continnum Publishing Company, 1993) lihat juga Gerardette Phillips, Melampaui Pluralisme, (Malang: Madani, 2016), 89-92.

42 Hans Küng, Global Responsibility in Search of a New World Ethic (New York: The Crossroad Publishing Company, 1991), 244.

43 Hans Küng, "Introduction: The debate on the word Religion," dalam Concilium, xii.
} 
dari aliran para filsuf lain. Mereka menamakannya sebagai 'sophia perennis' atau 'religio perennis'. Selain sebagai seorang filsuf perennial, Nasr juga disebut sebagai seorang tradisonalis dalam dialog antara agama. ${ }^{44}$

Sebagai tradisionalis, Nasr bersama tokoh inspirasinya melihat ada kesalahan dalam menafsirkan agama oleh aliran filsafat modern dan postmodern. Seperti Rene Guẻnon yang melontarkan kritik terhadap dunia modern yang berfokus pada tiga wilayah eksposisi utama yaitu metafisika, inisiasi, dan simbolisme. ${ }^{45}$ Domain sentral dari ketiga wilayah ini dipahami dalam istilah tradisi. Ananda Coomaraswamy menelisik lebih dalam soal hubungan spiritual yang menyatukan simbolisme, estetika, kontemplasi dan karya artistik. Pendalamannya ini terlihat dalam banyaknya perhatian pada Buddhisme, Neo Platonisme ${ }^{46}$ dan mistisisme Kristen. ${ }^{47}$ "Simbolisme dalam tulisan-tulisannya tidak hanya satu museum referensi dan korespondensi, tapi suatu lokakarya hidup dari transformasi spiritual." 48

Sementara Frithjof Schuon memiliki kecenderungan untuk fokus pada religio perennis ${ }^{49}$ daripada sophia perennis ${ }^{50}$ yang konsen pada tradisi.

\footnotetext{
44 Bdk. Gerardette Phillips, Melampaui Pluralisme (Malang: Madani, 2016), 145.

45 Gerardette Phillips, Melampaui Pluralisme (Malang: Madani, 2016), 146.

46 Rangkaian terakhir dari fase Helenisme Romawi, yaitu suatu fase pengulangan ajaran Yunani yang lama, jadi aliran ini masih berkisar pada filsafat Yunani, yang teramu dalam mistik (tasawuf Timur), dan juga digabung dengan berbagai aliran lain yang mendukung. Akibatnya, di dalamnya kadang terjadi tabrakan antara filsafat Yunani dengan agamaagama samawi. Terdapat unsur-unsur Platonisme, Phytagoras, Aristoteles, Stoa, dan mistik Timur, jadi, berpadu antara unsur-unsur kemanusiaan, keagamaan dan mistik.

47 Filsafat dan praktik tentang pengalaman langsung tentang Tuhan. Meskipun 'pengalaman' adalah suatu istilah yang hangat diperdebatkan dalam pembicaraan mengenai mistisisme, dan bahwa pengalaman yang dipahami semata-mata sebagai keadaan atau kejadian psikologis yang selalu dapat direfleksikan.

48 Didasarkan pada kumpulan artikel yang diterbitkan dalam buku, Beacon of KnowledgeEssays in Honor of Seyyed Hossein Nasr (Fons Vitae, 2003), 245-246.

49 Sebuah sudut pandang dalam filsafat agama yang meyakini bahwa setiap agama di dunia memiliki suatu kebenaran yang tunggal dan universal yang merupakan dasar bagi semua pengetahuan dan doktrin religius.
} 
Dari ketiga tokoh penafsir aliran filsafat perennial dan tradisionalis ini, Nasr mengakui bahwa intelektual dan spiritualnya lebih cenderung terinspirasi dari Schuon, namun ia lebih memilih untuk memakai istilah Philosophia Perennial ketimbang religio perennis.

Nasr punya tiga hal menggambarkan cara mentransformasi semangat intelektual dan spiritual. Pertama, sebagai seorang tokoh publik, punya banyak kesempatan untuk berbicara dalam berbagai forum. Partisipasi dan terlibat dalam forum lintas agama di PBB semakin membuka keluasan kerjasama dengan berbagai latar belakang. Kedua, sebagai penulis perennialis yang dekat dengan aliran agama tertentu. Ketiga, penulis perennialis yang memahami secara mendalam kekeliruan-kekeliruan sains yang terputus dari prinsip metafisik dan keceroboan ilmu modern yang mengabaikan hakekat nilai dalam tradisi peradaban manusia. Hingga banyak kalangan menjulukinya "empat dimensi utama Nasr." Pertama adalah sang Gnostik. ${ }^{51}$ Kedua adalah sang esoteris. ${ }^{52}$ Ketiga adalah pembangkit intelegensia dan pendidik spiritual Islam. Keempat adalah sang penafsir Islam bagi audiens Barat. ${ }^{53}$

Dari gambaran di atas kita menemukan dengan jelas posisi filosofis Nasr adalah Filsafat Perennial. Nasr memaknai perennialismenya dari aspek deduksi ke induksi. Ia melihat secara universal unsur-unsur esensial kemanusiaan, kemudian direfleksikan ke dalam diri. Refleksi intelektual yang dalam, menggiringnya untuk

\footnotetext{
50 Sebuah sudut pandang dalam filsafat agama yang meyakini bahwa setiap agama di dunia memiliki suatu kebenaran yang tunggal dan universal tetapi pemaknaannya berdasarkan tradisi, ritual, dan simbol yang hidup.

51 Bermacam-macam gerakan keagamaan yang beraliran sinkretisme pada zaman dahulu kala. Gerakan ini mencampurkan pelbagai ajaran agama, yang biasanya pada intinya mengajarkan bahwa manusia pada dasarnya adalah jiwa yang terperangkap di alam semesta.

52 Pemikiran yang sistematis dan komprehensif tentang struktur semesta dan letak manusia dalam semesta yang diajarkan hanya pada kelompok atau komunitas tertentu, atau sesuatu yang sangat internal, khas.

53 Patrick Laude, "Seyyed Hossein Nasr in the Context of the Perennialist School" dalam buku Beacon of Knowledge - Essays in Honor of Seyyed Hossein Nasr (Fons Vitae, 2003), 245-246.
} 
beranjak dari intuisi-intuisi metafisik sekaligus kearifan intelektual. ${ }^{54}$

Nasr membagi dua konsep pemahaman manusia yaitu rasional dan intelektif. Rasional lebih pada pengetahuan umum yang diyakini bersama, bisa melalui cara doktrin. sedangkan intelektif adalah kemampuan khas dari dalam, secara subyektif terangsang dari intuisi internal manusia ke objektivitas pengetahuan umum. Bagi Nasr intelektif adalah sumber ilmu pengetahuan. Secara mendasar Nasr juga membuat pembedaan antara akal budi dan kecerdasan. Akal budi adalah kemampuan alamiah, sedangkan kecerdasan adalah kemampuan yang didapatkan melalui relasi duniawi. Berbeda dengan para filsuf yang memisahkan epistemologi dan ontologi, Nasr justru memadukan.

Nasr juga membedakan dua dimensi dasar mentalitas manusia. Pertama, "esoteris", yang memberikan ruang gerak melampui bentukbentuk rasional dan artistik yang beranjak dari intuisi intelektual. Baginya cinta adalah dasar dari intuisi intelektual manusia. Kedua, "eksoteris", yang memberikan ruang gerak secara eksklusif pada bentukbentuk rasionalitas dan artistik. Bagi kaum eksoteris ${ }^{55}$ jika sesuatu tidak memiliki bentuk dan batas-batas tertentu maka ia bukan apa-apa. Konsep tak terbatas merupakan suatu abstraksi.

Nasr mendefinisikan konsep tradisi seperti ini: kebenaran dan prinsip-prinsip asal-usul ilahiah diungkapkan atau disingkapkan kepada umat manusia dan dalam kenyataannya seluruh sektor kosmik melalui berbagai tokoh digambarkan sebagai para utusan, nabi, avataras, logos, atau agensi-agensi transmisi lainnya untuk mewujudkan dalam kebersamaan. Menurutnya ada prinsip-prinsip yang mengikat manusia ke surga, dan karena itu agama dalam nilai esensialnya mengikat

\footnotetext{
54 Hahn L. E., Rendall E. A. \& Stone L. W. (eds), “The Philosophy of Seyyed Hossein Nasr", The Library of Living Philosophers (Illinois: Open Court Publishing Company, Vol. XXVIII, 2001), 142.

55 Pemikiran filsafat mengenai proses evolusi dari manusia dan makhluk hidup lainnya. Ilmu tentang akumulasi dari kebijaksanaan dari zaman ke zaman secara universal, jadi pengetahuan umum.
} 
manusia pada asal-usulnya. ${ }^{56}$ Pemahaman ini mendasari semua ajaran tradisional dan filsafat perennialnya dari dimensi metafisika. Dalam filsafat perennial realitas hidup dan apa yang kita alami tidak ditentukan oleh dunia psikofisik di mana manusia berfungsi, begitu juga kesadaran manusia yang tidak serta-merta terbatas pada pengalaman hidup yang dialami, lebih dari itu kehidupan dan pengalaman manusia berlangsung dan memiliki makna secara hierarkis atas semesta dalam kesadaran untuk memahami dan memaknai pengalaman hidup dengan bereksistensi pada kehadiran yang lain.

Agama adalah sarana utama bagi manusia dalam menelusuri perjalanan menuju tahapan yang lebih rendah dari keberadaannya ke kehadiran ilahiah, perjalanan ini tidak lain dari kehidupan manusia itu sendiri sebagaimana yang dipahami secara tradisional. ${ }^{57}$ Nasr sebagai salah satu tradisionalis menolak untuk mereduksi keberadaan agama hanya pada wilayah terrestial dan temporal. Karena agama bukan hanya iman dan praktik kolektivitas, juga bukan hanya iman dan keyakinan, melainkan realitas keilahian yang menjelma dalam hidup manusia. Ada pemaknaan pada realitas atas sesuatu yang misteri menyerupai kosmos itu sendiri. ${ }^{58}$

Refleksi mendalam atas filsafat perennial dan aliran tradisional inilah mengantarkan Nasr pada penjelajahan secara bebas melintasi batas-batas keberagaman agama. Seluruh hidupnya adalah suatu pencarian yang sakral. Pencarian panjang atas pengetahuan yang semakin besar, dalam doa tradisional Islam adalah rabbizidni ilman yakni "ya Tuhan tingkatkan pengetahuan saya". Pencarian yang membebaskan dan melepaskan kita dari belenggu dan keterbatasan duniawi. ${ }^{59}$

\footnotetext{
56 Seyyed Hossein Nasr, Knowledge and the Sacred (Lahore: Suhail Academy Pakistan, 1988), 68.

57 Seyyed Hossein Nasr, Traditional Islam in the World (London: Kegan Paul International, 1990), 56.

58 Ibid., 56.

59 Seyyed Hossein Nasr, In Search of the Sacred: A Conversation With Seyyed Hossein Nasr on His Life and Thought (ABC-CLIO, 2010).
} 
Pengalaman keagamaan ini tidak terlepas dari perjalanan hidupnya di negeri yang mayoritas Muslim, seorang Muslim di sekolah Kristen mengantarkan Nasr pada refleksi untuk mengerti dan memahami secara langsung pengalaman iman agama yang berbeda. "Nasr menyadari betul mengenai hidup dengan banyak agama, pengalaman pribadi sebagai seorang Muslim yang belajar di Barat telah menghadapkan saya pada realitas sebuah dunia multi-agama".60

Nasr memperjelas: "Yang-Satu tidak bisa ada dalam yang banyak tapi muncul, Dalam penciptaan seperti halnya dalam bentuk-bentuk sakral ini, Yang, beragam dalam penampakan mereka, Mengejawantahkan satu Cahaya ruhani, kekal. Aku menatap pada wajah-Mu dalam ketunggalan, Betapa bingung saya melihat banyak Wajah-Mu sekarang ini".61 Melalui kutipan ini, Nasr ingin berbagi pengalaman atas refleksi perjalanan hidup dan perjumpaannya dengan multiagama.

Menurutnya, melintasi batas-batas agama tanpa kehilangan orientasi dan dengan kesadaran penuh akan realitas yang sakral, yang tidak dapat direduksi pada kategori yang lain, mungkin merupakan tugas religius dan teologis yang paling menakutkan sekarang ini dan satu-satunya tantangan baru yang sangat penting dalam dunia wacana keagamaan manusia kontemporer. ${ }^{62}$

Tidak ada agama yang bisa hidup tanpa citarasa akan yang mutlak dalam wujud hidup bersama. Perwujudan tersebut tampak dalam keberagaman yang dirajut. Saling menghargai dan mengakui keunikan dan kekhasan masing-masing baik ritual maupun tradisi. Baginya, tantangan dalam dialog agama adalah merelatifkan semua agama adalah sama. Ini berbahaya karena tidak memperhatikan dua hal yaitu sejarah agama yang tentunya berbeda-beda dan inti agama adalah iman dan

\footnotetext{
60 W. Chittick, The Essential Seyyed Hossein Nasr (Canada: World Wisdom, 2007), 3.

61 Seyyed Hossein Nasr, Religion and Order of Nature (New York: Oxford University Press, 1996), 9.

62 Ibid., 11.
} 
komitmen pada muatan etis manusia untuk beragama secara abadi. Bahkan tidak menghargai keunikan agama lain.

Nasr menegaskan bahwa tradisi mempelajari agama dari sudut pandang scientia sacra ${ }^{63}$ yang membedakan antara Yang-Prinsip dan manifestasi, esensi dan bentuk, Substansi dan kecelakaan, yang batini dan yang jasmani. Yang Mutlak hanya ada pada Yang Mutlak. Kesatuan agama dapat ditemukan terutama dalam Yang-Absolut ini yang serentak Kebenaran dan Realitas dan asal-usul semua wahyu dan semua kebenaran. Seperti doktrin para sufi bahwa Persatuan adalah unik. Dalam keunikan itu ada misteri pada pencarian bahwa hanya pada tingkat Yang-Mutlak ajaran-ajaran agama adalah sama. ${ }^{64}$

Bagi Nasr yang paling penting untuk diperhatikan dalam studistudi agama adalah bagaimana melestarikan kebenaran agama, ortodoksi tradisional, struktur teologis dogmatis dari agama seseorang, mendapatkan pengetahuan tentang tradisi-tradisi lain dan menerima mereka sebagai cara dan jalan yang sahih secara spiritual menuju Allah. ${ }^{65}$ Keberagaman adalah bentuk, persatuan adalah esensi, yang merupakan wujud kehadiran beragam asal-usul segala sesuatu dalam misteri penciptaan yang unik dan khas dengan kemungkinan-kemungkinan tak terbatas.

\section{Simpul Etika Global dan Filsafat Perennial}

Dalam konteks diskursus pluralisme: memahami ajaran, keyakinan, dan klaim kebenaran teologis adalah kekhasan internal yang perlu dihargai oleh sesama. Lebih dari itu, semua agama bukan hanya sistem peninggalan sejarah masa lalu, bukan juga sekadar peradaban dengan segala aspek teroritisnya, tetapi realitas yang sudah menjelma

\footnotetext{
63 Scientia Sacra adalah inteligensia yang menyatukan antara wahyu eksternal dan wahyu dalam diri manusia yaitu hati.

64 Seyyed Hossein Nasr, Knowledge and the Sacred (Lahore: Suhail Academy Pakistan, 1988), 292-3.

65 Seyyed Hossein Nasr, Sufi Essays (Chicago: ABC International Group, 1999), 127.
} 
dalam peradaban manusia.

Maka menurut Küng, melalui dokumen justifikasinya berpendapat secara hakekat manusia itu individu namun dalam kenyataan hidupnya, ia tidak bisa menghindar dari kehidupan bersama orang lain untuk saling menilai dan mengakui sebagai implikasi sosio-etis hidup sosialnya. Nasr mengungkapkan hubungan kesatuan spiritual dari simbolisme, estetika, kontemplasi dan artistik. Baginya ini semacam museum referensi sebagai lokakarya hidup dalam mentransformasi semangat spiritual.

Karena penekanannya lebih pada tradisi agama-agama maka di kalangan Islam menjuluki Nasr dengan empat dimensi utama dalam filsafat perennialnya. Pertama, gnostik. Kedua, sang esoteris: bagaimana spirit nilai internal diimani secara mendalam sebelum beranjak mewujud ke ruang hidup sosial. Ketiga, pembangkit inteligensia Islam sekaligus pendidikan spiritual: ia menginspirasi dan menarik perhatian kaum inteligensia Islam untuk bergerak bersama membawa damai. Keempat, dinobatkan sebagai penafsir Islam bagi audiens Barat: ini didasarkan pada pengalaman nyata keberimanan Islam itu sendiri. Küng lebih menekankan pada pengalaman dan interaksi hidup, tradisi naratif, hermeneutika dan konteks budaya yang hidup. Oleh karenanya, ia mengusulkan perlunya emansipatoris politis tidak hanya sosial etis.

Bagi Küng, Tuhan adalah Tuhan bagi sesama (seluruh) umat manusia, sehingga keselamatan itu diperoleh apabila Tuhan itu hadir dalam masing-masing kita untuk saling berbagi kepada sesama, sebagai ungkapan universalitas yang melintasi batas-batas budaya dan agama. Ia menitikberatkan pada apa yang menyatukan ketimbang apa yang memisahkan. Sehingga perlu bersama mengembangkan suatu nilai yang dapat diterima semua orang. Nasr membangun dialog yang beranjak dari unsur esensial manusia yang diyakini bersama yaitu intelek. Karena baginya inilah yang menentukan identitas manusia untuk saling memahami keberagamannya. 
Küng dengan "Etika Globalnya" mengajak kita untuk memahami 'dari dalam', bagaimana cara agama lain melihat Tuhan dan dunia, baik juga terhadap sesama, ada kemantapan juga dalam berpolitik, berlaku adil dalam hukum, punya dimensi etis dalam merumuskan pandangan kepada sesama yang berbeda. Sedangkan Nasr dengan "Filsafat Perennis"-nya, memberikan gagasan bahwa di ujung pemahaman keagamaan sebagai manusia beriman ujungnya atau muaranya ternyata sama. Hanya saja caranya berbeda-beda menuju ke sana. Sehingga, semua umat beriman perlu melihat inti universalnya, yakni berpaling dari aspek "eksoteris" ke aspek "esoteris" agama-agama.

Dalam Filsafat Perennis, Nasr merujuk pada kesatuan transendental yang melampui bentuk-bentuk manifestasi dimensi eksternal. Kesatuan tersebut bukan penyamarataan melainkan kesatuan hakiki yang terbentuk dari keunikan yang berbeda-beda. Pada tingkat yang lebih dalam, masing-masing agama punya kualitas nilai yang khas dan ciri-ciri yang tidak boleh diabaikan. Sedangkan Etika Global, Küng merujuk pada norma etis yang tidak tertulis namun menjadi landasan atau pedoman hidup masyarakat dalam membangun kehidupan bersama di antara keragaman tersebut. Adalah "etika primal" 66 di mana pola pembentukan etika universal didasarkan pada ruang dan waktu, konteks peristiwa hidup masyarakat yang dinamis. Semacam nilai-nilai inti bersama dalam tatanan sosial secara global guna membingkai dialog yang beranjak dari pranata individu ke masyarakat. Karena manusia selain sebagai individu, ia juga meleburkan diri ke dalam masing-masing pribadi sebagai masyarakat.

Intinya sebagai wahyu ilahi, perbedaan antara agama tampak dalam cara memanifestasikan kebenaran dan tindakan religius untuk mengungkapkan kuasa Tuhan atas manusia melalui tradisi yang berbeda-beda. Pluralisme agama dalam hidup manusia adalah sebuah fakta peradaban tentang keberadaan manusia dengan berbagai

66 Nilai-nilai dasar yang terbuka untuk semua orang. 
dimensinya, baik: ideologi, tradisi, ritual dan simbol adalah realitas yang sudah jelas-jelas terbukti. Kendati ada perbedaan, baik: bentuk, praktik, budaya, makna itu merupakan kesatuan esensial yang mewujud ke dalam diri manusia tentang yang ilahi. Yang berbeda agama dengan kita adalah kita dengan agama dalam wajah yang lain. Kendati ada perbedaan dalam agama, semua pemeluk agama pada dasarnya adalah satu entitas hakiki yaitu sesama sebagai manusia.

Gagasan dan rumusan antara Küng dan Nasr dalam konteks dialog agama ini sebenarnya sebuah gagasan komprehensif dalam bingkai dialog yang memberikan ruang dan waktu untuk membangun kerjasama antar-agama yang disasarkan pada aspek semangat kemitraan. Maka dalam tafsiran saya, "Etika Global" merupakan perumusan ulang seperangkat nilai, moral dan standar etika sebagai konsensus universal yang dapat diterima oleh semua agama. Sedangkan, "Filsafat Perennial" melihatnya dari sudut pandang tradisi. Karena melalui tradisi dalam agama-agama, masing-masing orang dengan iman agamanya akan memahami bentuk dan makna sakral tanpa merusak keabsolutan agamanya juga agama yang lainnya. Sekaligus menegaskan soal konsep kemutlakan bahwa Yang-Mutlak adalah mutlak. Semua agama pada tingkat absolut dan kemutlakan adalah sama. Cara manifestasinya saja yang berbeda.

Dari gagasan-gagasan keduanya yang dipaparkan di atas maka, menurut penulis paling tidak ada tiga simpul relevan dalam berdialog saat ini. Pertama, keterbukaan pada klaim-klaim kebenaran dari masingmasing agama. Kita perlu memahami dan mengerti bahwa semua agama dan keyakinan mana pun di dunia ini selalu punya alasan logis yang meyakini para pemeluknya untuk berargumentasi pada posisi klaim kebenaran yang diyakininya. Kedua, etika dalam merespon relativisme. Baik Küng maupun Nasr sangat berhati-hati dalam menggagas diskursus mengenai pluralisme, sehingga keduanya bisa dengan jeli melihat kemungkinan bahkan kelemahan dari pluralisme yang ternyata akan bermuara pada relativisme ajaran-ajaran agama. Ketiga, apresiasi dan 
pengakuan pada keunikan masing-masing. Seperti sudah disinggung di atas bahwa semua agama dan keyakinan selalu punya ciri khas yang unik dan semua punya alasan yang masuk akal. Sehingga keduanya menawarkan kepada semua pemeluk agama untuk memahami etika keagamaan seseorang dengan membawa orang ke kedalaman agamanya sendiri melalui warna-warni keberagaman agama. Apresiasi dan pengakuan ini menurut penulis sebagai wujud keberanian dan keterbukaan untuk saling menerima perbedaan, saling memberikan pengertian, saling memaafkan atas kesalahpahaman, bekerjasama sebagai mitra yang saling melengkapi sekaligus memaknai kedalaman makna atas keyakinan yang diyakini.

\section{Dialog sebagai Cara Baru Beragama}

Sejak awal penciptaan, manusia adalah individu, dibentuk sebagai pribadi sekaligus masyarakat. Konteks individu yang dibentuk inilah menunjukkan ada proses menjadi ke suatu arah dan tujuan bersama. Proses sebagai sebuah evolusi kesadaran akan realitas hidup yang otentik. Agama dengan bermacam aliran kepercayaan dan keyakinan adalah realitas. Berhadapan dengan realitas tersebut, setiap pribadi yang dibentuk dalam masyarakat, sekaligus sebagai umat beriman disapa untuk mengambil sikap. Karena semua agama, dewasa ini semakin memperjelas pemahaman akan sikap bahwa masing-masing agama mempunyai makna hidup bermasyarakat.

Dialog merupakan kepeduliaan pada sesama baik dari aspek sosiologis maupun aspek teologis. Dialog bukan hanya sebuah keharusan, melainkan ada penghargaan dan bagaimana cara kita menempatkan "yang lain" dari perspektif "saya", sekaligus menempatkan "saya" dalam perspektif "yang lain".67 Dialog melahirkan sikap simpatik untuk merangkul yang lain. Berhadapan dengan beragamnya umat beragama, kita akan mendengarkan, membiarkan diri disapa oleh iman

67 Ibid., 16. 
dan kehidupan mereka. Bersama-sama berusaha untuk saling mengerti dan memahami. ${ }^{68}$

Dialog sebagai cara baru beragama, di mana beranjak dari pengalaman inti manusia lahir, hidup dan bertumbuh. "Pengalaman inti suatu agama adalah pengalaman liberatif yang melahirkan agama itu dan terus-menerus ditawarkan kepada generasi-generasi selanjutnya".69 Vitalitas iman beragama bergantung pada semangat keterlibatan untuk mengantarkan para pemeluknya ke dalam pengalaman inti liberatif. ${ }^{70}$ Tradisi dan praktek hidup beragama, rumusan ajaran, simbol dan ritual religius: menjadi bingkai interaksi dan mediasi untuk menciptakan suasana perjumpaan antaragama. Terlibat untuk saling menyapa dalam perjalanan historikal-kultural yang berbeda-beda namun meleburkan diri dalam realitas pengalaman iman beragama.

Dengan itu, kesadaran perlahan-lahan muncul dari pranata "individual" ke kelompok "masyarakat". Kesadaran yang dalam pandangan teolog seperti John Hick dan Knitter adalah adanya pengakuan akan kebenaran dengan cara yang berbeda-beda. Fitzgerald dan Borelli memperjelas bahwa pluralisme agama itu mengacu pada keberagaman agama yang terlibat. Karena perbedaan tradisi khususnya agama dalam masyarakat adalah fakta keberagaman. Ini menjadi nyata apabila ada keberanian untuk saling mendorong sebuah proses dialog yang secara langsung ke dalam realitas hidup bersama. Dengan ini ada keberanian pula untuk saling mengintip setiap perbedaan dan keunikan masing-masing agama. Ada pengakuan dan apresiasi antara sesama agama sebagai mitra dialog.

Sebab agama adalah fenomena kemasyarakatan, pandangan hidup yang mengandalkan iman pada dimensi transenden atau wahyu

\footnotetext{
68 J. B. Banawiratma, "Bersama Saudara-saudari Beriman Lain, Perspektif Gereja Katolik" dalam Dialog: Kritik \& Identitas Agama (Yogyakarta: DIAN/Interfidei, 1993), 16.

69 Ibid.,17.

70 Keterbukaan pada dimensi-dimensi etis bersama secara universal.
} 
khusus. ${ }^{71}$ Saling memberikan kesempatan untuk menjelaskan diri kita sendiri dalam bahasa kita dan siap untuk menjadikan semua ini sebagai syarat-syarat di mana kita memahami siapa kita dan apa yang kita percayai. $^{72}$

Mengingat subyek yang bertuhan dan beragama itu, manusia yang sama-sama tinggal di bumi yang sama dengan matahari yang juga sama, pilihan keyakinan dan tawaran keselamatan hidup yang melampaui batas dunia hendaknya jangan menghancurkan tata kehidupan di bumi. Yang mesti diusahakan adalah terjadinya kesesuaian (taufik) antara kehendak Langit dan kreasi manusia di bumi. Tuhan yang diyakini sebagai sumber kasih mesti diwujudkan dalam kehidupan sosial yang diikat dengan tali kasih (silaturahim). Sikap keberagamaan hendaknya mendatangkan rahmat bagi semesta. ${ }^{73}$

Dalam konteks Indonesia yang terkenal dengan Pancasila, dari gagasan Küng dan Nasr paling tidak ada lima implikasi praktis yang perlu diperhatikan untuk dialog beragama. Pertama, pendidikan agama sebaiknya lebih menekankan pada sosiologi beragama. ${ }^{74}$ Harus ada pembedaan wilayah teologi beragama dan sosiologi beragama. Ini membiasakan anak didik untuk mewujudkan iman agama dalam praktek hidup sehari-hari. Kita semua akan paham soal realitas perjumpaan dengan insan yang berbeda. Karena sosiologi beragama lebih fokus pada gambaran bagaimana agama hadir dalam realitas hidup bersama. Intinya, pendidikan agama harus menggiring setiap generasi beralih dari ajaran ke praktek hidup bersama. Harus secara langsung terjun ke dalam peristiwa hidup masyarakat. Ini bisa memakai metode live in melalu kerja sama antara lembaga pendidikan lintas agama atau bisa juga dengan kunjungan ke rumah ibadah agama lain. Tentunya melalui program

\footnotetext{
71 Ibid., 19.

72 Gerardette Phillips, Melampaui Pluralisme (Malang: Madani, 2016), 272.

73 Komaruddin Hidayat, "Fitrah Manusia Ber-Tuhan", Kompas, 27 Juli 2015.

74 Lebih menekankan agama pada praktek hidup sehari-hari, bagaimana segenap umat beriman meleburkan diri dalam peristiwa hidup nyata, dengan itu pemahaman mengenai pentingnya keberadaan orang lain yang berbeda agama akan tercipta secara alamiah.
} 
pendidikan yang terintegrasi.

Kedua, dialog kultural. Kekayaan kebudayaan Nusantara yang beragam dan estetik bisa menjadi modal untuk masuk dalam dialog agama karena ada tradisi yang hidup, ada simbol estetik yang berwarna, lalu ada universalitas nilai yang terpatri dalam peradaban kebudayaan yang melekat secara alamiah. Ini bisa diwujudkan melalui kegiatan festival seni dan budaya yang melibatkan dan bertema mengenai keberagaman.

Ketiga, terbukanya ruang publik bersama. Ini mungkin lebih berperan adalah otoritas yang mengatur kehidupan bersama. Kesediaan untuk berpartisipasi dalam kegiatan publik, diskusi bersama sebagai upaya untuk terus menghidupkan dialog yang intens. Dengan terbiasa hadir dalam ruang publik yang terbuka maka akan ada inisiatif publik untuk saling merangkul dan mengajak dalam perbedaan dan terbiasa pula bertemu dengan keragaman. Ini ada contoh menarik dari Bandung, di mana Walikota Ridwan Kamil menata kembali taman-taman kota sebagai ruang publik yang ramah untuk warga bisa berkumpul, guyub, dan beraktivitas sesuai keinginan dan komunitas hidupnya.

Keempat, memupuk semangat keterlibatan. Pada bagian ini kita saling mendorong untuk terlibat, bekerja sama lintas golongan, bersama mengembangkan rasa solidaritas sosial dalam dialog agama yang bermakna. Belajar dari pengalaman, di Bandung komunitas lintas agama sering bahkan rutin melaksanakan kegiatan bakti sosial di daerah-daerah yang membutuhkan bantuan.

Kelima, menciptakan suasana perjumpaan. Fenomena intoleransi belakangan muncul karena dialog yang terjalin selama ini kecenderungannya pada situasi yang dikondisikan secara formal. Hal ini yang membuat kita kaku dalam beberapa hal dalam dialog agama. Yang harus diciptakan adalah suasana perjumpaan informal. Bagaimana orang tanpa sadar meleburkan dirinya dalam keberagaman agama. Ini akan menciptakan suasana interaksi dan interelasi antara umat beragama secara alamiah, tanpa ada kecurigaan apapun. Pemahaman mengenai 
perbedaan dalam agama akan terjelma dengan sendirinya. Pribadipribadi yang berdialog akan sangat santai dan hadir penuh kerendahan hati, suasana yang tentunya sangat dinamis. Pengakuan dan apresiasi pada sesama yang berbeda juga akan tercipta secara spontan. Spontanitas inilah yang melahirkan ketulusan dalam berdialog.

Kita selama ini lebih menyesakkan pemahaman agama hanya pada tataran ajaran yang mengarah pada abstraksi sekaligus mengabaikan pembiasaan pribadi untuk berinteraksi dalam mengeksplorasi imannya, imajinasi, hasrat, nalar, moralitas, kecerdasan emosional, serta spiritualitas keterlibatan dalam kehidupan sosial. Sebaliknya eksplorasi iman, moral, hasrat, spiritualitas keterlibatan harus menjadi konstruksi sosial yang hidup dan terbiasa sekaligus teralami dalam realitas sosial kemasyarakatan.

Konteks dialog seperti ini, tidak selamanya harus dikondisikan secara formalitas. Melainkan informalitas saja. Misalkan saja adanya festival kebudayaan tahunan antara pelajar, pameran seni nusantara dengan tema-tema mengenai kehidupan umat beragama, konser musik bersama lintas agama dan budaya, atau semacam "tur silahturahmi" nasional khususnya di hari lahir Pancasila sebagai hari untuk saling mengunjungi antara sesama. Ini sebagai model bagi kehidupan umat beragama yang mana tidak langsung berkutat dengan dimensi teologis melainkan "menciptakan suasana perjumpaan" antara manusia sebagai "pribadi" dan "masyarakat". Kalau kita memulai dengan masalah teologis maka akan berujung pada klaim-klaim kebenaran yang justru menciptakan sekat-sekat antaragama. Melalui seni dan kebudayaan orang akan lebih terbuka terhadap yang lain. Dalam bahasa Luc Ferry: "universalitas konkret".

\section{Penutup}

Dari rumusan di atas, dapat dikatakan bahwa agama merupakan sebuah sistem. Sistem ini kemudian berbicara mengenai struktur. Sistem akan berjalan dengan baik kalau ada keteraturan, ada peraturan, dan ada 
pengatur. Rumusan dalam sistem beragama adalah ajaran dan doktrin, baik dalam Kitab Suci sebagai pedoman penting agama-agama, maupun aturan yang lain. Sistem ini memungkinkan individu terjalin dengan yang lain dan berbagai tautan pranata hidup bermasyarakat.

Agama berperan penting dalam mengedepankan, memelihara, dan mengembangkan humanitas. Ajaran-ajaran yang sarat dengan kerelaan untuk memperhatikan, mencintai, dan menjaga sesama kiranya cukup untuk mengatakan bahwa agama tidak mengabaikan nilai-nilai kemanusiaan yang memang dicari dan dibutuhkan manusia. Ini terlihat dengan beragam ritual dan simbol yang hidup dalam agama. Ritus dan simbol yang beragam merupakan ekspresi nilai-nilai yang diyakini, dihayati, dan dihidupi oleh setiap pemeluk agama. Rasa peduli dan mau berbagi dengan sesama adalah kesadaran bahwa semua ada keterkaitan. Agama dalam peradaban manusia telah melahirkan tokoh inspirasi yang mengedepankan cinta pada sesama dan hadir menyerukan perdamaian.

Hans Küng dengan "Etika Global" dan Seyyed Hossein Nasr dengan "Philosophia Perennial" merupakan sosok ketokohan yang sudah selesai dengan pergumulan hidup beragama. Keduanya merumuskan cara baru dalam dialog beragama, bukan sekadar rumusan, melainkan melalui refleksi perjalanan spiritual yang pelik, sudah jauh melangkahi kerumitan perdebatan mengenai simpul teologis agama-agama. Keduanya sudah dengan mantap dalam iman agamanya masing-masing hingga berani meleburkan diri dalam keberimanan yang berbeda. Dalam konteks itu, konsep "Etika Global" dan "Filsafat Perennis" memberikan inspirasi baru bagi dialog beragama di era postmodern. Karena bagi Küng dan Nasr puncak ajaran beragama adalah cinta pada sesama.

Sejak dulu di bumi Indonesia tumbuh beragam agama. Mereka mungkin sekali meyakini Tuhan Yang Esa, sebagai pencipta dan pengatur semesta, tetapi mengambil jalan yang berbeda-beda sehingga muncul pluralitas agama dan aliran kepercayaan. ${ }^{75}$ Sebagai kekayaan dan

75 Komaruddin Hidayat, "Fitrah Manusia Ber-Tuhan", Kompas, 27 Juli 2015. 
identitas bangsa, agama dalam tradisi Indonesia adalah sumur nilai, tempat kita menimba kebijaksanaan untuk membangun habitus keindonesiaan yang berdasarkan Pancasila. ${ }^{76}$ Sebab, Pancasila adalah "kumpulan saya" yang dengan sadar membayangkan dan mengakui diri sebagai kita dalam keutuhan sebagai bangsa yang bernama Indonesia, untuk selalu berefleksi dan bersandar pada puncak tata nilai yang otentik yaitu Pancasila.

76 Boni Hargens, "Indonesia dan Titik Nol", Kompas, 5 April 2017. 